\title{
Comparison of two coprological methods for the veterinary diagnosis of fasciolosis
}

[Comparação de dois métodos coprológicos para diagnóstico da fasciolose]

\author{
F. Kleiman, S. Pietrokovsky, S. Gil, C. Wisnivesky-Colli \\ Departamento de Ciencias Biológicas - $4^{\circ}$ piso, Pabellón II \\ Facultad de Ciencias Exactas y Naturales - Universidad de Buenos Aires \\ Ciudad Universitaria, Av. Cantilo s/n, C1428EHA \\ Buenos Aires, Argentina
}

\begin{abstract}
The sensitivity and utility of a standard faecal sedimentation method (FSM) and a modified stool sieving staining method (FSSM), both currently employed for the diagnosis of Fasciola hepatica infection were compared. Faecal samples were obtained from 51 bovines of an endemic area for fasciolosis in Southwestern Argentina. Each sample was placed in a recipient containing 5\% formalin. Eight millilitres of the suspension, equivalent to $2 \mathrm{~g}$ of faeces, were used for each of the two methods tested. The number of eggs found per sample was recorded. The proportion of positive samples obtained by the FSSM $(27 / 51)$ was significantly higher than that by the FSM $(11 / 51)(\mathrm{P}<0.05)$. The percent of agreement between methods was $41 \%$. Over a total of 27 positive samples detected by the FSSM, the FSM missed 16 , yielding $60 \%$ false negative samples. The FSSM enhanced 2.5 times the sensitivity of diagnosis. The complexity of the FSM may decrease its sensitivity through missing and loss of eggs during sample processing. These results confirmed that the commonly used FSM underestimates the prevalence and the egg output in cattle and that the FSSM is a more reliable diagnostic method.
\end{abstract}

Keywords: cattle, Fasciola hepatica, coprological method, diagnosis

\section{RESUMO}

Compararam-se a sensibilidade dos métodos padrão de sedimentação fecal (MPSF) e modificado da tamisação e coloração das fezes (MTCF)-quatro tamises, ambos empregados no diagnóstico de infecção por Fasciola hepatica. Amostras de fezes foram obtidas de 51 bovinos oriundos de uma área endêmica por fasciolose no Sudoeste da Argentina. Cada amostra foi colocada em um recipiente contendo formalina 5\%. Oito mililitros da suspensão, equivalente a $2 \mathrm{~g}$ de fezes, foram usados em cada método testado, registrando-se o número de ovos por amostra. A porcentagem de amostras positivas pelo MTCF (27/51) foi maior que a apresentada pelo MPSF (11/51), o que representou 60\% de amostras falsonegativas. A porcentagem de concordância pelos dois métodos foi 41\%. A complexidade do MPSF pode diminuir sua sensibilidade pela perda de ovos durante o processamento. Estes resultados confirmaram que o MPSF subestima a contagem de ovos e que o método MTCF é mais confiável.

Palavras-chave: bovino, Faciola hepatica, método coprológico, diagnóstico

Financial support: Secretaría de Ciencia y Técnica - Universidad de Buenos Aires y Agencia Nacional de Promoción Científica y Tecnológica

Recebido para publicação em 14 de outubro de 2003

Recebido para publicação, após modificações, em 24 de março de 2004

E-mail: fkleiman@bg.fcen.uba.ar 


\section{INTRODUCTION}

Fasciolosis in cattle, caused by Fasciola hepatica, is a worldwide disease of major economical importance (Boray, 1985; Hope Cawdery, 1984). Although the presence of the parasite is usually confirmed by the detection of eggs in faeces (Ward et al., 1997; Anderson et al., 1999), novel diagnostic methods such as coproantigen capture ELISA tests have been developed. These tests are more sensitive than the coprological methods, thus allowing the early detection of active infection by immature flukes (Duménigo et al., 2000). However, parasite presence revealed by the detection of coproantigens does not imply actual oviposition. Besides, these immunological methods provide no information on the number of eggs shed or on the proportion of definitive hosts spreading eggs into the environment, which are valuable variables for epidemiological studies since the offer of potentially infective miracidia to local snail populations shapes the dynamics of the $F$. hepatica transmission cycle. Therefore, coprological methods provide specific information, which cannot be replaced by any other type of diagnostics.

A coprological method frequently used, includes formalin and ether as solvents and centrifugation to concentrate eggs (Ritchie, 1948; Shore García, 1973; OMS, 1994). This method was adapted to be used under field conditions and in nonsophisticated diagnostic laboratories by replacing centrifugation with spontaneous sedimentation (Dennis et al., 1954; Grock et al., 1998). In order to eliminate large faecal debris, the sieving of faeces prior to sedimentation was incorporated into this technique (Zukowski et al., 1993; Grock et al., 1998; Anderson et al., 1999; Parr and Gray, 2000).

Simple sieving methods to collect helminth eggs from faeces have been reported. For instance, in the quantitative method by Girão and Ueno (1994), the stools were filtered through a set of stacked sieves of different mesh size after being diluted in a detergent solution. Prior to examination under stereoscopic microscope, the material retained in the lowermost sieve was stained with methylene blue to highlight the presence of eggs, as previously described by Boray and Pearson (1960). Even simpler was the technique modified by Dixon and Wescott
(1987), which involved sieves to process the samples and omitted the use of detergent and staining. Besides, a commercial technique ${ }^{1}$ is available in the market. It is similar to the method described by Girão and Ueno (1994) and the manufacturers claim it is $100 \%$ efficient, but no published data are available.

No studies, until the present, comparing the efficiency between the sedimentation and sieving methods have been conducted. Thus, this study aimed to compare both methods in terms of sensitivity and utility for the veterinary diagnosis of $F$. hepatica infection.

\section{MATERIALS AND METHODS}

Faecal samples were obtained from 51 bovines born and raised in an endemic area for fasciolosis in southwestern Argentina. To avoid crosscontamination between samples, each one was directly collected from the rectum of the animal with disposable gloves. About $20 \mathrm{~g}$ from each sample were individually placed in identified recipients containing $80 \mathrm{ml}$ of $5 \%$ formalin (about one volume of faeces to three volumes of preservative, as recommended by the $\mathrm{CDC}^{2}$, 2002, which were vigorously shaken for homogenisation. Eight millilitres of the suspension -equivalent to $2 \mathrm{~g}$ of faeces- were used for each of the two methods tested. Stool was preserved in formalin because cold chain could not be ensured under field conditions and samples could not be examined within the prescribed time interval.

In the faecal sedimentation method (FSM), samples were processed using a modified version of Shore García's sedimentation technique (1973). Each fixed sample was vigorously shaken and filtered through gauze. Eight $\mathrm{ml}$ of the suspension were poured into a $10 \mathrm{ml}$ centrifuge tube and $2 \mathrm{ml}$ of saline solution were added. After homogenisation, the suspension was centrifuged at 1500 RPM $(174 \mathrm{~g})$ for $2 \mathrm{~min}$. The supernatant was then removed, the tube was refilled with $5 \%$ formalin to bring the volume up

${ }^{1}$ Flukefinder ${ }^{\circledR}$, Visual Difference, Idaho, USA.

${ }^{2} \mathrm{CDC}$. Identification and diagnosis of parasites of public health concern: diagnostic procedures for stool specimens - 7/10/2002. http://www.dpd.cdc.gov/DPDx/ HTML/DiagnosticProcedures.html 
to $10 \mathrm{ml}$ and the suspension was homogenised and centrifuged once more. After removing the supernatant, the pellet was resuspended in $7 \mathrm{ml}$ of $5 \%$ formalin and $3 \mathrm{ml}$ of ether. After the last centrifugation, pellets yielded between 25 and 30 slides each $(20 \times 20 \mathrm{~mm}$ coverslips $)$, which were examined under optical microscope at 100x. A sample was considered positive when at least one egg was found in the whole pellet. The number of eggs present in each sample was recorded.

A sieving-staining method (FSSM) was performed based on a previous work by Girão and Ueno (1994), modified to improve simplicity. Eight $\mathrm{ml}$ of faecal suspension were individually filtered through a set of three stacked sieves. Sieves were of 250, 125 and $53 \mu \mathrm{m}$ mesh each $(40,120$ and 270 US Standard Size, respectively), from top to bottom, with a diameter of $20 \mathrm{~cm}$. The first two sieves retain large particles while the lowermost allows the collection of $F$. hepatica eggs. Following filtration, the set was thoroughly rinsed by spouting tap water through the topmost sieve and this procedure was repeated taking away one sieve at a time. Finally, the $53 \mu \mathrm{m}$ mesh sieve was tilted and rinsed gently with water to transfer small particles into a Petri dish. The faecal debris was stained with a few drops of $1 \%$ methylene blue to differentiate between plant matter (blue) and yellow eggs of $F$. hepatica (Boray and Pearson, 1960). Search for eggs was performed under stereoscopic microscope at 20x using transmitted light illumination. All eggs found were counted. To avoid contamination between samples, all sieves were thoroughly washed upside down with tap water before re-use.

To test the accuracy of this method, $100 \mathrm{~F}$. hepatica eggs obtained from the uterus of an adult specimen were added to a negative $8 \mathrm{ml}$ faecal suspension, which was subsequently processed as explained above. All the material (either retained by the three sieves or passing through the lowermost screen) was examined under stereoscopic microscope. All the eggs were retained in the $53 \mu \mathrm{m}$ mesh sieve, thus confirming the efficiency of the washing procedure and the suitability of the sieves used.

The $\chi^{2}$ test was used to compare the proportions of positive faecal samples obtained by the FSM and the FSSM (Fleiss, 1981). The percent of agreement (PA) between methods was calculated according to Gordis (2000) as the number of positive samples by both methods divided by the number of samples that were positive for at least one method, multiplied by 100 .

\section{RESULTS}

The results of positive and negative samples according to the method used are shown in Table 1. Out of 51 samples tested, 11 (21\%) were positive by the FSM while as many as 27 (53\%) were positive by the FSSM. The proportion of positive samples obtained by the FSSM was significantly higher than that by the FSM $(\mathrm{P}<0.05)$.

Table 1. Frequency of positive and negative samples resulting from the faecal sedimentation method (FSM) and the faecal sieving - staining method (FSSM)

\begin{tabular}{lccc}
\hline \multirow{2}{*}{$\begin{array}{l}\text { Number of samples } \\
\text { by FSM }\end{array}$} & \multicolumn{3}{c}{ Number of samples by FSSM } \\
\cline { 2 - 4 } & Positive & Negative & Total \\
\hline Positive & 11 & 0 & 11 \\
Negative & 16 & 24 & 40 \\
Total & 27 & 24 & 51 \\
\hline
\end{tabular}

Because 11 samples were positive by both methods, 16 were positive by the FSSM and negative by the FSM, and no positive samples by the FSM and negative by the FSSM were found, the percent of agreement was $41 \%(11 / 27)$. Out of 40 negative samples by the FSM, 16 were positive by the FSSM, but none of the 24 samples negative by the FSSM was detected as positive by the FSM. Taking into account that the FSM missed $60 \%(16 / 27)$ of positive samples, the FSSM increased 2.5 times the sensitivity of diagnosis.

The number of eggs found in the 11 concordant positive samples was considerably different. All samples examined by the FSM but only $4(36 \%)$ of those processed by the FSSM had 1 or 2 eggs per 2 gram of faeces (ep2g) each. The 7 remaining samples processed by the FSSM yielded between 6 and $35 \mathrm{ep} 2 \mathrm{~g}$ each. On the other hand, out of the 16 discordant samples, $50 \%$ yielded less than 2 eggs each, and the remainder between 3 and 16 eggs. 


\section{DISCUSSION}

Methods including screens are widely used in many regions, although their efficiency has not been documented before. Data obtained in this study provide the first experimental evidence that the FSSM is more efficient and reliable than the standard FSM for the diagnosis of fasciolosis in cattle.

Some main factors influencing egg detection in coprological tests are the length and intensity of the infection, the difficulty in obtaining serial samples under field conditions, and laboratorydependent variables (Ward et al., 1997). Because the first three items apply equally to both methods compared in this work, differences may rely on the degree of complexity of each method. The FSM includes numerous steps that increase the chance of losing eggs, as demonstrated by the lower number of eggs recorded in this work. Eggs may remain in the debris while filtering the faeces through gauze, or may get stuck on the bottom and walls of the recipient and within the pipette when recovering the pellet for microscope observation. On the contrary, the FSSM includes one-step operating procedure in which all eggs, if present, are collected from the lowermost sieve.

On the other hand, eggs missed out by the FSM may be attributed to the observer's fatigue because of the large number of slides required for examining a whole sample, a procedure that can last for approximately 2 hours. Moreover, eggs may be masked by large faecal debris. By contrast, the FSSM requires examining up to two Petri dishes per sample and the average time spent to check up an entire sample is reduced to approximately 15 to 20 minutes. The use of stereoscopic microscope, together with the fact that eggs stand out from a blue background, make egg examination faster and easier.

The FSSM has many well-known additional advantages when compared to the FSM. Because of its simplicity, the FSSM can be implemented both under laboratory and field conditions, reduces the time needed to process numerous samples, and facilitates the processing of large volumes of suspension if faeces are fixed, or different stool weights if kept fresh. Although in the present work samples had to be fixed, in subsequent studies faeces could be kept fresh until examination without requiring the use of highly toxic substances such as formalin and ether.

There are some operational differences among the FSSM and previous coprological tests involving the use of sieves. Concerning the number of sieves, the time spent in sample processing becomes shorter as the number of screens used decreases. However, minimising them to two may lead to pore blockage, particularly when stools are very dense. Therefore, the use of three sieves appears to be an adequate solution to deal with the compromise between both time spent and reliable results. On the other hand, a detergent solution was used by Girão and Ueno (1994) and Zukowski et al. (1993) to facilitate egg suspension before filtration. In this work, the use of detergent was omitted after verifying that no eggs were retained by faecal debris during sample processing. In addition, unlike Zukowski et al. (1993), there was no need to perform serial sedimentation after sieving since eggs collected in the lowermost sieve were easily distinguished from the rest of the material.

Unfortunately, no comparison could be done with the Flukefinder ${ }^{\mathbb{R}}$ set, since the protocol is not available unless purchasing the product. However, when Abidu et al. (1996) compared this commercial technique with the sieving method developed by Girão and Ueno (1994), they found that both methods had the same sensitivity, but the latter was fast, simple and less expensive.

The use of the FSSM enhances the chance of finding eggs specially when there is a low intensity of infection and egg shedding, either by regular chemical treatment or by a low transmission level. Moreover, the FSSM may allow a better and more accurate estimation of economical losses when these are calculated from prevalence and egg counts (Malone, 1994).

In brief, any sieving system consisting of a set of stacked screens will be more efficient and useful than the sedimentation method for the diagnosis of fasciolosis, if the number of screens and the size of their meshes allow differential passage of the debris without pore blockage and the eggs are retained in the finest mesh. 


\section{ACKNOWLEDGEMENTS}

We wish to thank Establecimiento Los Murmullos for providing valuable cooperation and field facilities, and veterinarian Jorge Gomez Castañón for his help with stool collection. We also thank the Departamento de Microbiología y Parasitología e Inmunología de la Facultad de Medicina, Universidad de Buenos Aires for technical assistance and laboratory facilities.

\section{REFERENCES}

ABIDU, M.; SCHERER, P.O.; SILVA CARNEIRO, V. et al. Estudo comparativo entre técnicas coproparasitológicas para diagnóstico de Fasciola hepatica em bovinos. Rev. Bras. Ciênc. Vet., v.3, p.1-3, 1996.

ANDERSON, N.; LUONG, T.T.; VO, N.G. et al. The sensitivity and specificity of two methods for detecting Fasciola infections in cattle. Vet. Parasitol., v.83, p.15-24, 1999.

BORAY, J.C. Flukes of domestic animals. In: GAAFAR, S.M.; HOWARD W.E.; MARSH R.E. (Eds.). Parasites, pests and predators. World Animal Science, Elsevier, 1985. p.179-218.

BORAY, J.C.; PEARSON, I.G. The anthelmintic efficiency of tetrachlorodifluoroethane in sheep infested with Fasciola hepatica. Aust. Vet. J., v.36, p.331-336, 1960 .

DENNIS, W.R.; STONE, W.M.; SWANSON, L.E. A new laboratory and field diagnostic test for fluke ova in feces. J. Am. Vet. Med. Assoc., v.124, p.4750,1954

DIXON, R.C.; WESCOTT, R.B. A fast and accurate fecal examination technique for diagnosis of Fasciola hepatica. In: ANNUAL MEETING OF THE AMERICAN ASSOCIATION OF VETERINARY PARASITOLOGISTS, 3., Portland. Proceedings... Portland: AAVP, 1987. p.28. (Abstract)

DUMÉNIGO, B.E.; ESPINO, A.M.; FINLAY C.M. et al. Kinetics of antibody-based antigen detection in serum and faeces of sheep experimentally infected with Fasciola hepatica. Vet. Parasitol., v.89, p.153-161, 2000.
FLEISS, J.L. Statistical methods for rates and proportions. 2.ed. New York: John Wiley \& Sons, 1981.255p.

GIRÃO, E.S.; UENO, H. Técnica quatro tamises metálicos. In: UENO, H.; GONÇALVES, P.C. Manual para diagnóstico das helmintoses de ruminantes. 3.ed. Japan International Cooperation Agency and Universidade Federal do Rio Grande do Sul, Porto Alegre, Brazil, 1994. p.62.

GORDIS, L. Assessing the validity and reliability of diagnostic and screening tests. In: EPIDEMIOLOGY. 2.ed. Pennsylvania: W.B. Saunders, 2000. p.63-81.

GROCK, R.; MORALES, G.; VACA, J.L. et al. Fascioliasis in sheep in the human high endemic region of the northern Bolivian Altiplano. Res. Rev. Parasitol., v.58, p.95-101, 1998.

HOPE CAWDERY, M.J. Review of the economic importance of fascioliasis in sheep and cattle. Ir. Vet. News, v.7, p.14-22, 1984.

MALONE, J.B. The landscape epidemiology of fasciolosis: geographic determinants of disease risk. In: BORAY, J.C. (Ed.). Immunology, pathobiology and control of Fasciolosis. CONFERENCE ICOPA, 8., 1994, Izmir, Turkey. p.65-81.

OMS. Medios auxiliares para el diagnóstico de las parasitosis intestinales. Francia: Servicios Gráficos de la OMS, 1994. p.1-6.

PARR, S.L.; GRAY, J.S. A strategic dosing scheme for the control of fasciolosis in cattle and sheep in Ireland. Vet. Parasitol., v.88, p.187-197, 2000.

RITCHIE, L.S. An ether sedimentation technique for routine stool examinations. Bull. U.S. Army Med. Depart., v.8, p.326, 1948.

SHORE GARCÍA, L.; ASH, L.R. Diagnóstico parasitológico. Buenos Aires: Panamericana, 1973. $157 \mathrm{p}$.

WARD, M.P.; LYNDAL-MURPHY, M.; BALDOCK, F.C. Evaluation of a composite method for counting helminth eggs in cattle faeces. Vet. Parasitol., v.73, p.181-187, 1997.

ZUKOWSKI, S.H.; WAYNE WILKERSON, G.; MALONE, J.B. Fasciolosis in cattle in Louisiana. II. Development of a system to use soil maps in a geographic information system to estimate disease risk on Louisiana coastal marsh rangeland. Vet. Parasitol., v.47, p.51-65, 1993. 